\title{
DEVELOPMENT OF EURO-REGIONAL COOPERATION OF UKRAINE IN THE CONTEXT OF THE VISEGRAD EXPERIENCE
}

\author{
Vitalii Petruk, Elena Kovtun* \\ National University of Life and Environmental Sciences of Ukraine, Kyiv, Ukraine
}

The goal of this paper is to analyze the dynamics of cooperation of Ukraine with the Visegrad countries with the aim to integrate into the political, economic, legal and humanitarian space in Europe and build the benchmark for system reforms to modernize Ukraine. Therefore, the study of problems of Euroregional cooperation is essential, given the complex circumstances surrounding the modern integration processes. The need to take into account the experience of regional policy of the Visegrad countries in the context of globalization and expansion of the EU influence is undeniable. Multilateral cooperation of Ukraine with the countries of Visegrad during the last decade is characterized by significant achievements. The close historical ties and common foreign policy goals of modern Ukraine and Visegrad laid the foundation for effective development of good neighbourly relations at the present stage and created opportunities for further large-scale cooperation in the future. It is safe to say that Visegrad-Ukrainian relations are rather balanced, thanks to the successful implementation of bilateral and multilateral agreements achieved after the regular meetings at all levels. All this creates a solid foundation for further expansion of this cooperation on the basis of the joint account of the interests of the parties.

Keywords: Visegrad, Ukraine, euroregional cross-border cooperation, regional development

\section{Introduction}

With the independence of Ukraine and the increasing role of international cooperation of the state and regional development in strengthening the economy, scientists turned their attention to the processes and phenomena occurring within the cross-border regions.

One form of realization of cross-border cooperation is a Euroregion. A Euroregion is an institutionalized form of cross-border cooperation; it is the highest level in the hierarchy. Also, the Euro-regional cooperation is a cooperation of Euroregions, which serve as subjects of cooperation (Mikula, 2010).

In 1990-ies, Ukraine crystallized foreign policy orientation towards integration into the European community. European choice opens new prospects for Ukraine's cooperation with the developed countries of the continent, economic development, social and intellectual progress, strengthening the position of the state in the international system of coordinates.

European integration for Ukraine is the way to modernize the economy, attracting foreign investments and new technologies, increasing the competitiveness of domestic producers, the possibility of entering the single EU internal market.

In the political aspect of the EU, integration of Ukraine determines modernization of the legal framework, democratization of its political and institutional systems, cooperation with the EU, facilitating approximation of social conditions of Ukraine to the highest European standards, better living standards and welfare. In the cultural aspect of the EU, integration of Ukraine is the way to increase the interchange between Ukrainian and Western European culture, the simultaneous formation of Ukraine as an integrated part of the global society and the independent state. Finally, the EU integration guarantees the national security of Ukraine, the protection from the aggression and territorial claims. Ukraine is already beginning to see a number of benefits from its closer ties with the EU. The EU recently extended its unilateral trade agreement with Ukraine until the end of 2015, which gives the latter's battered economy one-way preferential access to
EU markets without either the Association Agreement or DCFTA (Deep and Comprehensive Free Trade Agreement) ratification by all EU member states.

However, in the process of the relations development between Ukraine and the EU, negative factors will act inevitably: for example, increased competition from the EU enterprises in the process of liberalization and the increasing openness of the national economy, accompanied by the elimination of non-competitive enterprises with negative social consequences (Mykhasiuk and Fedyshyn, 2011).

\section{Material and methods}

The paper has an explorative character. The data were used from the official open data source - the State Statistics Service of Ukraine.

Our research was carried out via the following steps:

$\square$ we compared available literature resources dealing with our research issue with respect to Programs of cross border cooperation for V4 countries and Ukraine;

$\square$ secondly, data were examined separately for each country-member of V4 for the different period in case of investments in - and trade with Ukraine;

$\square$ thirdly, the results from both groups - development of the sector and development of the legislation for individual years were matched;

$\square$ then, the matched data were compared with each other;

$\square$ finally, the comparisons were analysed and discussed.

The integration of Ukraine into the European structures in the process of the EU integration requires developing and implementing a new model of relations with the regions that would meet the principles of regional policy of the European Union.

\section{Regulatory support}

An important role in regional cooperation coordination played legal acts and regulations at the regional level, activities of European regions and areas for regional cooperation based on signed contracts and intergovernmental agreements, agreements and decisions of cooperation between local 
governments and local authorities of the administrative-territorial units of countries belonging to the European regions, agreement implemented in whole areas of the territory and the territory of the European regions. Thus, on Euroregion "Bug", cross-border cooperation is regulated by 22 agreements and other solutions, "Lower Danube" - 4, "The Carpathian Euroregion" - 34, "Upper Prut" - 15 "Dnepr" - 2 "Sloboda" - 2 (Havrys, 2002).

Regional development strategy and Euroregional cooperation found significant additions in the annual Presidential Address to the Verkhovna Rada Ukraine, which identifies the main vectors of modernization of regional policy and regional development potential. In this context, the State Strategy for Regional Development until 2020 is extremely important.

Practical implementation of the innovative approaches to the development of a new regional policy provides a number of measures to modernize the tools of regional development in Ukraine in different directions.

\section{Programs of cross-border cooperation}

Due to the statementreleased by theV4 (December 2014), the group will divide its assistance efforts towards Ukraine into four areas. Slovakia will assist in supporting reforms of the energy security and security sector, the Czech Republic will help in building civic society, media and education, Poland will coordinate decentralization and public finance reform, and Hungary will support small and medium enterprises (Michnik, 2015).

The Visegrad 4 Eastern Partnership program (V4EaP) was initiated in 2011 by the V4 governments to enhance the cooperation between the countries of the Visegrad region and countries of the Eastern Partnership (EaP): Armenia, Azerbaijan, Belarus, Georgia, Moldova and Ukraine. The main goals of this cooperation are enjoyment the unique know-how of the V4 countries with social and economic transformation, democratization and regional cooperation including the development of civil society and support of cooperation among local governments, educational and scientific institutions (universities, colleges etc) and citizens.

\section{Results and discussion}

Ukraine has received new perspectives in its cooperation with the EU through Euro-regional strategies that represent a new and promising answer by the EU to the growing number and diversity of member states. Let's analyse the dynamics of investments between V4 countries and Ukraine with respect to the close cooperation. However, it must be noted that Ukrainian customs statistics should be treated with caution because they may not always reflect the real state of affairs. Official counterpart statistics from the Visegrad countries are contradictory and there are cases when Ukrainian data is higher or vice versa, probably due to tax-avoidance schemes on the Ukrainian side (Zsuzsa, 2005).

The structure of Slovakia investments in Ukraine is presented below (the economy of Ukraine attracted USD $75.1 \mathrm{mln}$ investments from Slovakia, which is about $0.2 \%$ of the total amount of foreign investment in Ukraine (Figure 1)).
The amount of Polish investments in Ukraine is $775.5 \mathrm{mln}$ USD (01.04.2015), representing $1.9 \%$ of the total foreign investment in Ukraine. Since the beginning of 2015 Polish investments declined by $55.7 \mathrm{mln}$ USD. This is due to the political and military challenges in Ukraine (Figure 2).

Overall, the share of the V4 in total Ukrainian foreign trade turnover is significant. The largest trading partner in 2014 is Poland, followed by Hungary, the Czech Republic, and Slovakia.

In 2013, the amount of direct investments from Hungary into Ukraine was about 686

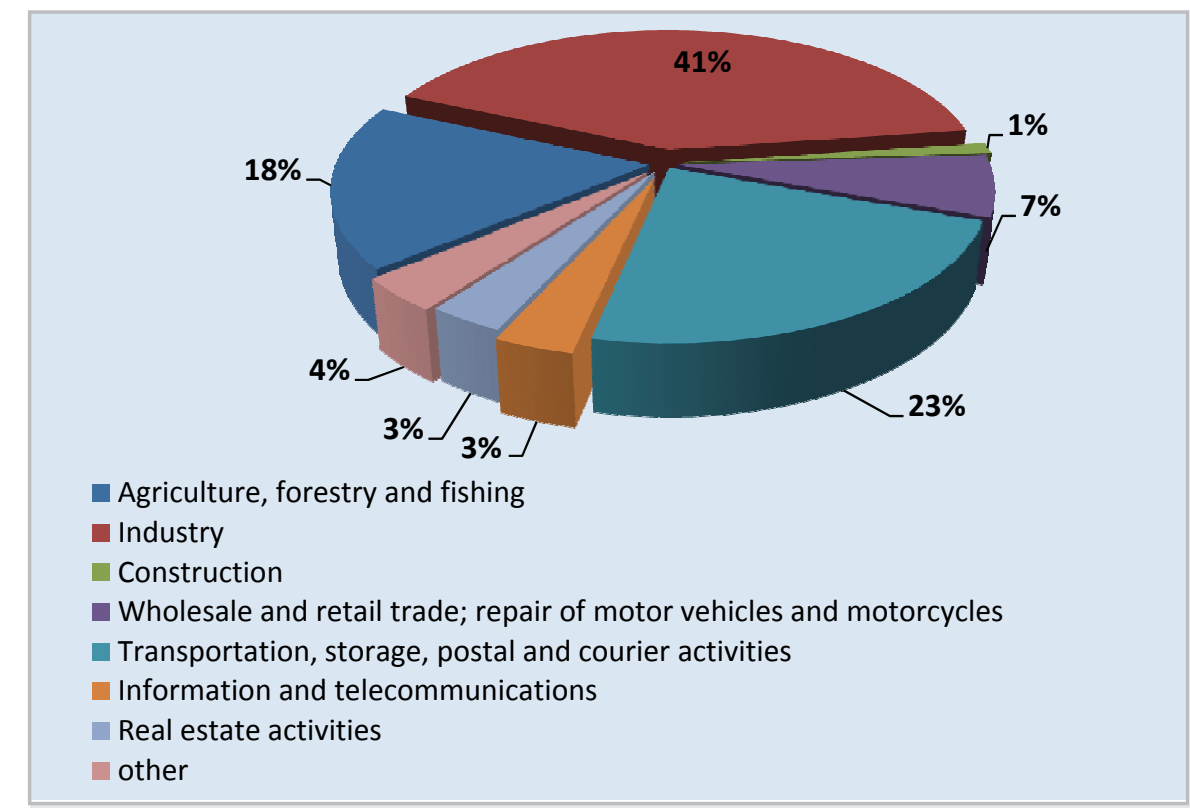

Figure 1 The structure of Slovak investments in Ukraine, 2014 Source: State Statistics Service of Ukraine

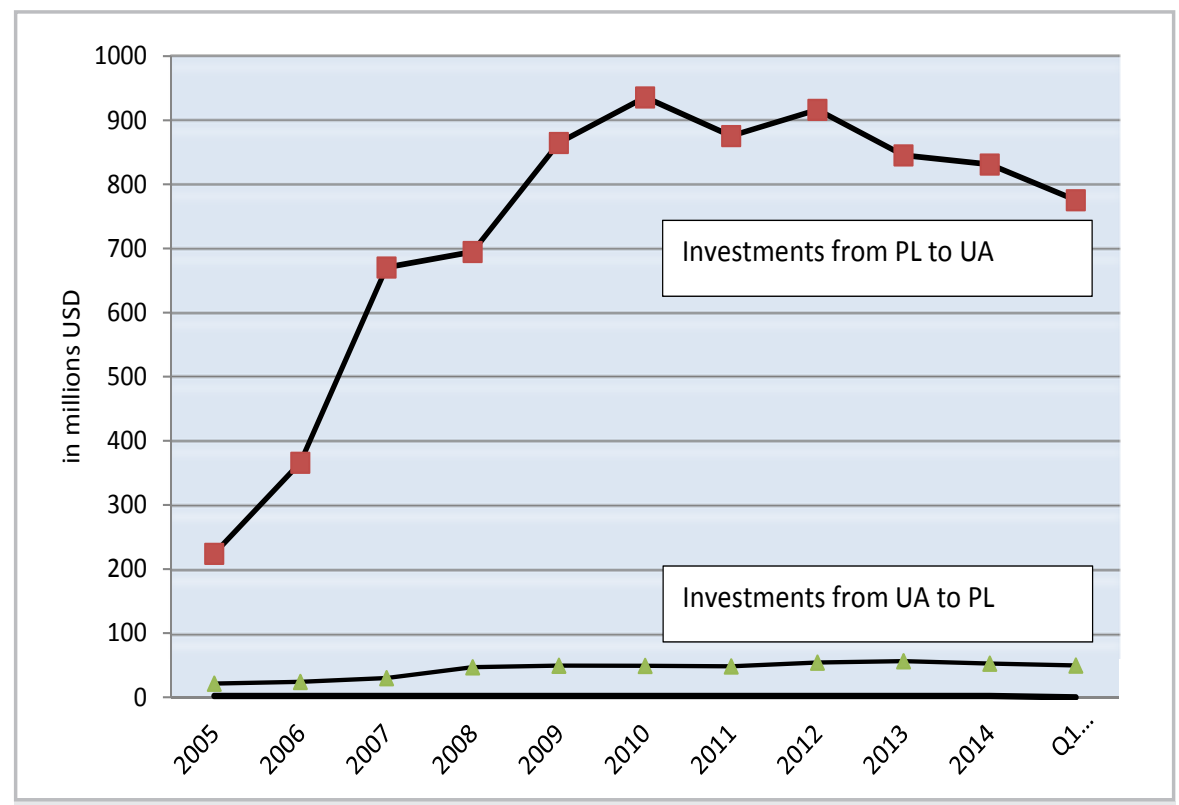

Figure 2 The dynamics of the Ukrainian-Polish investment cooperation in mIn USD Source: State Statistics Service of Ukraine 
Table 1 The Dynamics of direct investments from Hungary in Ukraine

\begin{tabular}{|l|l|l|l|l|l|l|}
\hline & 2008 & 2009 & 2010 & 2011 & 2012 & 2013 \\
\hline Investments in mIn USD & 411.2 & 595.4 & 711.5 & 700.5 & 681.4 & 685.8 \\
\hline
\end{tabular}

Source: State Statistics Service of Ukraine

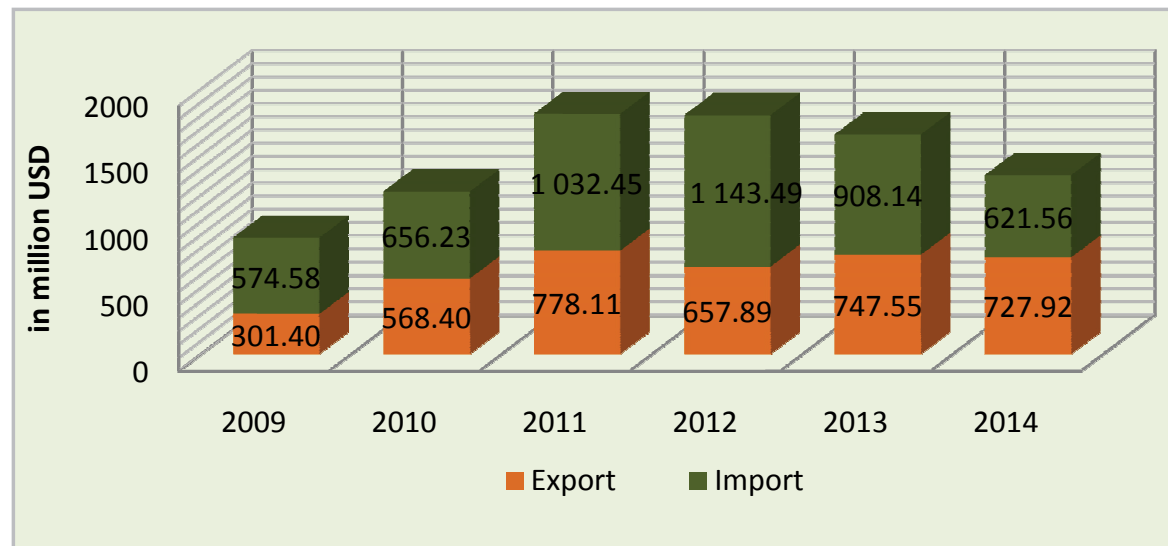

Figure 3 The dynamics of foreign trade turnover between Ukraine and the Czech Republic, 2013 Source: State Statistics Service of Ukraine

mln USD $(1.2 \%$ in the structure of total direct investments).

The greatest Hungarian investment is into Hungarian small and medium enterprises in the Transcarpathian region, where there are partners within the Hungarian ethnic minority.

As an example, consider the dynamics of trade turnover between Ukraine and the Czech Republic (Figure 3). Completion of the recession in the Czech economy in 2013 caused a slight growth in export of industry, construction. There was also marked increased demand in the EU market, and unlike in 2012 to 2013, there was an increase in exports from Ukraine iron ores and concentrates by $18.1 \%$.

Due to the same factors, in contrast to 2012, in 2013 there was an increase in exports to the Czech Republic ferrous metals by $2.9 \%$ and product of ferrous metals - by $42.7 \%$.

Currently, Ukraine increasingly supplies commodities that cannot be displayed the most positive way in trade balance.

Consistent and effective implementation mechanisms of the Association Agreement must create a solid basis for further sustainable political and economic development of Ukraine and make a good start of the reform strategy in the main areas of implementation of EU standards for quality of life in Ukraine.

\section{Conclusion}

Democratization of the economic life in Ukraine and the liberalization of markets, the decline in the level of protectionist barriers, the level of state presence in the economy, carrying out the administrative-territorial reform on the principles of subsidiarity and solidarity will strengthen the role of regional authorities in the intensification of the cross-border economic cooperation, which will completely implement the doctrine of strategic partnership between Ukraine and the Visegrad group countries.

Now it is possible to predict the following stages of development of cross-border cooperation between Ukraine and the countries of the Visegrad:

$\square$ a stage of adaptation of Ukraine to the European standards which is difficult and quite painful;

$\square$ a stage of realization of the potential development in cross-border cooperation, using new tools, incl. "Eastern Partnership" which will bring results in respect of social and economic development of cross-border territories of neighbouring countries (i.e. formation of system quality of crossborder cooperation; geographic location is convenient as a potential offshore zone for factories assembling products for the EU market etc).

However, despite developed deep and comprehensive interactions between the countries in various spheres and the reached joint achievements, an assessment of results of cooperation testifies to a number of the problem factors which slow down the development of both interregional and cross-border cooperations between the countries.

\section{References}

HAVRYS, J. 2002. Development strategy concerning the challenges of globalization. Lviv : NU "LP", 2002. pp. 139-147.

MICHNIK, W. 2015. Visegrad Group and Regional Consequences of the Russian-Ukrainian Conflict. Aailable at: <http://visegradplus.org/analyse/ visegrad-group-regional-consequences-russianukrainian-conflict/

MIKULA, N. 2010. Inter-territorial and cross-border cooperation. Monograph. Lviv : IRD Sciences of Ukraine, 2010.395 p.

MINISTRY OF FOREIGN AFFAIRS. 2014 Available at: $<$ http://www.mfa.gov.ua>

MYKHASIUK, I. R. - FEDYSHYN, C. 2011. Cross-border cooperation in the context of globalization, monograph (in Ukrainian). LNU named Franko, Ukrainian Technologies, Lviv.

PRESIDENCIES OF THE VISEGRAD GROUP. 2015/2016 Czech Presidency. Available at: <http://www. visegradgroup.eu/documents/presidencyprograms/20152016-czech>

STATE STATISTICS SERVICE OF UKRAINE. 2015. Available at: <http://www.ukrstat.gov.ua>

VARNALIYA, E. - NISS, 2007. State Regional Policy of Ukraine: features and strategic priorities. Monograph. Kiev, 2007. 768 p.

VASHCHUK, F. G. 2012.The priorities of the state strategy of regional development of Ukraine and the role of institutional associations in the process of its implementation. Uzhgorod: TSU, 2012.

ZSUZSA, L. 2005. What may the Visegrad countries offer to Ukraine with special regard to Hungary. In Fóti, G. - Zsuzsa, L. eds. Eurointegration Challenges in Hungarian-Ukrainian Economic Relations, Budapest : Institute for World Economics of the Hungarian Academy of Sciences, 2005. pp. 225-248.

\section{Contact addresses}

Dr. Elena Kovtun, National University of Life and Environmental Sciences of Ukraine, Heroyiv Oborony str. 11, Kyiv, Ukraine, phone: +380 445278 133, cell: +38067 5381 881, e-mail: ekovtoun@nubip.edu.ua 